\title{
Feasibility Report on $\mathrm{CO}_{2}$ Separation from Biogas in Post-Combustion Processes
}

\author{
Selen Ezgi ÇELİK ${ }^{1}$, Yıldız İPEKÇi் ${ }^{2}$, Özlem ÇELIKKASLAN ${ }^{3}$, Fatih GÜRELİ $\dot{I}^{4}$ and Hanifi SARAÇ
}

\begin{abstract}
Carbon capture and storage (CCS) technology is proposed as an effective pathway for restraining anthropogenic $\mathrm{CO} 2$ emissions from Landfill Gas (LFG) power plants. Desire to protect our climate has consequently motivated recent efforts to decrease energy consumption in industrial countries, improve energy efficiency, introduce renewable energy sources and CCS of $\mathrm{CO} 2$ from power plants Here we address the latter method of $\mathrm{CO} 2$ reduction, namely $\mathrm{CO} 2$ recovery from LFG. In this study, it is aimed to design biogas treating processes and $\mathrm{CO} 2$ separation in postcombustion processes. Theoretical approaches regarding the compared processes are discussed, and a new developed for the applications of the design is introduced. Taking into account the scope of design in actual processes CHEMCAD 6.5.6 software is used. This simulation can be used both in determining the minimum energy, area targets of a new plant to be constructed, in making necessary design alterations in an already existing plant.
\end{abstract}

Keywords-Biogas, CO2, Landfill Gas, Post Combustion, Simulation..

\section{INTRODUCTION}

$\mathrm{L}$ ANDFILLING is the most old fashioned and common way of treating the solid wastes. Hazardous waste storage is when the solid wastes are littered in which the produced gas and the leachate production are controlled. Landfilling is simply discharging the solid waste in the fields where the production of leachate is prevented and covered so as to turn it into a biological reactor. Landfilling field is formed by cells within. Those cells are filled sufficently with waste and in order to prevent leachate production it's cover with soil etc. With time the landfill gas is being produced naturally ans it's collected with vertical and horizontal pipes ans used as a fuel.[1]

Landfill gas is composed of a mixture of hundreds of different gases. By volume, landfill gas typically contains $45 \%$ to $60 \%$ methane and $40 \%$ to $60 \%$ carbon dioxide. Landfill gas also includes small amounts of nitrogen, oxygen, ammonia, sulfides, hydrogen,

Selen Ezgi ÇELIK ${ }^{1}$ is with the Yıldız Technical University Chemical Metallurgical Faculty, Chemical Engineering Department, Istanbul, TURKEY

Yıldız IPEKÇ ${ }^{2}$ She is now with the Yıldız Technical University Chemical-Metallurgical Faculty, Chemical Engineering Department, Istanbul, TURKEY

Özlem ÇELIKASLAN ${ }^{3}$ She is now with the Yildız Technical University Chemical-Metallurgical Faculty, Chemical Engineering Department, Istanbul, TURKEY

Fatih GÜRELI ${ }^{4} \mathrm{He}$ is now with Ortadoğu Energy Group, Kaptanpaşa Mh. Piyalepaşa Bulvarı Ortadoğu Plaza No:73, Kat:11, 34384 Okmeydanı, Şişli, Istanbul, TURKEY

Hanifi SARAÇ ${ }^{5} \mathrm{He}$ is now with the Yıldız Technical University Chemical Metallurgical Faculty, Chemical Engineering Department, Istanbul, TURKEY carbon monoxide, and nonmethane organic compounds (NMOCs) such as trichloroethylene, benzene, and vinyl chloride.

Typically landfill gas is combusted or used to generate electricity. Recently landfill gas is purified and afterwards used to generate heat/electricity.[1]

Landfill gasses pollute the environment in several ways, such as;disturbance of the smell released,threat to human health, prevention for new plants to arise, danger of explosion and fire [3] Additionally the landfill gas contributes the greenhouse effect amd damages the upper layers of ozone layes .With all these reasons described above, it's forbidden to release landfill gas directly into the atmosphere.[3]

LFG collection typically begins after a portion of the landfill (known as a "cell") is closed to additional waste placement. Collection systems can be configured as either vertical wells or horizontal trenches. Most landfills with energy recovery systems include a flare for the combustion of excess gas and for use during equipment downtimes. Every million tons of MSW in a landfill is estimated to be able to produce approximately 432,000 cubic feet per day of LFG. Through various technologies, the LFG could generate approximately 0.78 megawatts of power, or provide 9 million Btu per hour of thermal energy.[8]

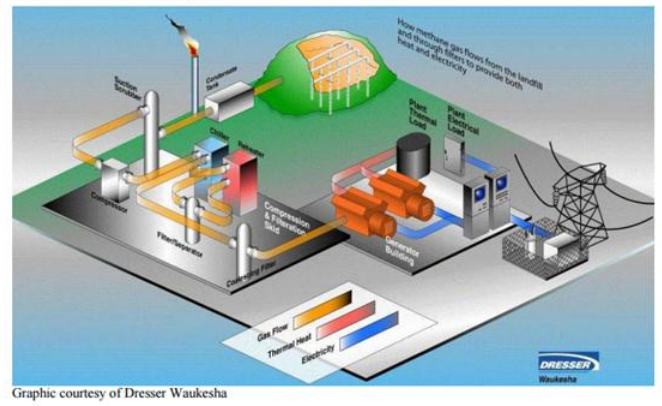

Fig. 1 Landfill Gas Collection, Treatment and Energy Recovery[8]

The three most commonly used technologies for LFG energy projects that generate electricity - internal combustion engines, gas turbines and microturbines - can accommodate a wide range of project sizes.

\section{RESEARCH GOAL}

Removing $\mathrm{CO}_{2}$ from the biogas is called the treatment and enrichment of biogas. After methane $\mathrm{CO}_{2}$ has is the second major compound. $\mathrm{CO}_{2}$ lowers the energy level of the biogas and becauseof this reason it's known as energy dilluter. In order to use biogas as natural gas or a fuel, the $\mathrm{CO}_{2}$ it contains need to be reduced. With the water vapor $\mathrm{CO}_{2}$ forms weak acids and causes corrosion. Also during compressing $\mathrm{CO}_{2}$ changes its from to dry ice.

Facilites which applies conducting technologies can be optimized and decrease the $\mathrm{CO}_{2}$ emission . Most important step is to minimize the energy requirement and increase the overall efficency. As a result 
new technologies are being developed in order to decrease the capital and overall costs. [12]

$\mathrm{CO}_{2}$ is removed in the natural gas industries regularly but not for storage. Today $\mathrm{CO}_{2}$ conducting technologies are not applired to the power power plants which generates hundreds of megawatss of $\mathrm{CO}_{2}$ emissions. With this paper, we attempt to clarify the potential role and place of membrane permeation processes inpost-combustion capture, and to close the gap between materials science and engineering studies. We begin this task by summarizing postcombustion capture conditions and identifying the corresponding separation targets. The separation performance of a single-stage membrane permeation unit is evaluated over a large range of selectivity values and operating conditions; these results are compared with experimental selectivity data from literature. Industrial facilities and for power plants there are 3 approaches:[13]

Post combustion Systems are removing $\mathrm{CO}_{2}$ in the flue gas which is produced after the combustion of coal, natural gas, petroleum or biomass. Post combustion is the most challenging one when the other methods are considered due to the treatment of dillued, low pressured and wet gas mixture.

Industrial Systems; contain chemical loops or pre-combustion alternatives. This method of $\mathrm{CO}_{2}$ conducting is being applied for 80 years but most of the $\mathrm{CO}_{2}$ removed is exhausted to atmosphere for the lack of storage intentions.

Pre-combustion Systems; has 2 sub-methods

Oxy-combustion, uses pure $\mathrm{O}_{2}$ instead of using air for combustion. Second method involves the reaction between syngas and $\mathrm{O}_{2}$ or air containing steamed fuel(mostly consists of $\mathrm{H}_{2}$ or $\mathrm{CO}$ ) $\mathrm{CO}$ and $\mathrm{C}_{\mathrm{O} 2}$ are sent to a catalytic reactor called 'shift conventor' in order to produce more hydrogen.

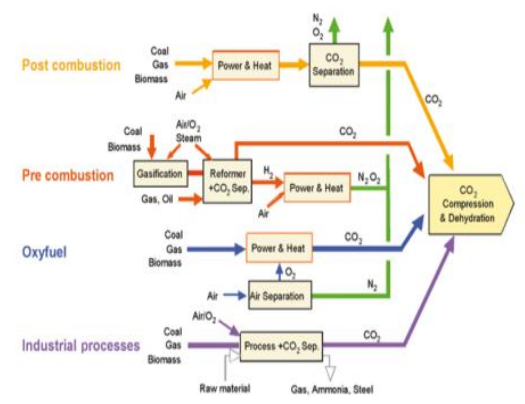

Fig 2: $\mathrm{CO}_{2}$ Capture Process Classifications [13]

There are two main methods in use for post combustion methods; coloumn separation and membrane separation.[13]

\section{Coloumn Separation:}

$>$ Pressurized Water Absorption (DWW)

> Physcial Absoption with Solvent/Sorbent (Seleksol, Genosorb)

$>$ Amine Absorption

$>$ Cryogenic Separation

$>$ Pressure Swing Adsorption (PSA)

\section{Membrane Separation}

The membrane separation of $\mathrm{CO}_{2}$ from biogas became very popular in last years. Various membranes have been tested to make the separation effective and feasible. Membrane processes can be classified in 2 groups [17]
A. Difference in Number of Stages ;

1. Single Step Separation

2. Multi-Step Separation

\section{B. Differences in Flow Type ;}

1. Counter or Cross Flow

2. Sweep Flow

\section{Differences in Number of Stages}

1. Single Step Membrane Processes

2. Multistage Membrane Processes

\section{DesCription Of Process ANd Model}

a.Amine Absorption Process Description

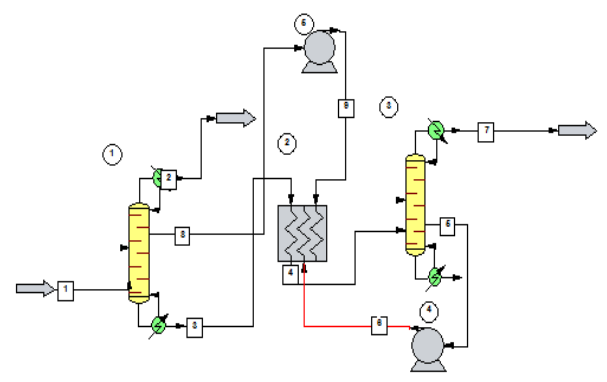

Fig 3: Process Flow Diagram for Coloumn Based Separations

Fig. 3 shows the schematic diagram of coloumn separation based $\mathrm{CO}_{2}$ capture process considered here, which includes following sections.

(1) CO2absorption :The flue gas from power plant contacted with aqueous absorbent in the $\mathrm{CO}_{2}$ absorber. The $\mathrm{CO}_{2}$ rich solution was then introduced into the $\mathrm{CO}_{2}$ a heat exchanger, and was heated in the to release $\mathrm{CO}_{2}$ and recover the absorbent in the solvent recorvery column. There is a heat exchanger between the absorption coloumn and ssolvent/absorbent recover column. Its duty was varied to release the same amount of $\mathrm{CO}_{2}$ as that absorbed in the absorber.

(2) Absorbent abatement and recovery. The vapor exiting the $\mathrm{CO}_{2}$ absorber contained high concentration od the solvent, usually over ten thousands ppmv, resulting from the high volatility of absorbent. A recovery column was set to remove absorbent/solvent with washing liquid. The flow rate of washing liquid was varied to maintain the absorbent/solvent concentration in the vent gas of washing column at $50 \mathrm{ppmv}$. The washing liquid then entered into the column after a heat exchanger and was heated to release absorbent and recover the washing liquid into the heat exchanger with a pump.

The flue gas containing $\mathrm{CO}_{2}$ enters the absorber and contacts the aqueous solution of MEA flowing counter currently to the flue gas stream. $\mathrm{CO}_{2}$, a weak base, reacts exothermically with MEA, a weak acid, to form a water soluble salt. The 'rich'MEA stream exits the absorber at the bottom of the column. It is then pre-heated in a heat exchanger by the lean MEA stream leaving from the bottom of the stripper, and is fed to the stripper where, with further addition of heat, the reaction is reversed. The $\mathrm{CO}_{2}$, having been stripped off from the MEA, leaves through the top of the strip-per column. The 'lean' MEA is then recycled back to the absorber. Chowdhury (2012) studied amine absorption process for post-combustion CO2capture from flue gases for different reaction chemistry (equilibrium and ratebased), tray sizing, tray rating, flooding, and foaming factors. Hassan et al. (2007) studied amine absorption for post combustion $\mathrm{CO}_{2}$ 
capture in RateFracTM (rate-based non-equilibrium model) and reported an economic evaluation of the process.

\section{Model Description:}

The amine absorption process simulation has been carried out with ChemCAD 6.3.1 and the model for the system proposed by $\mathrm{Yu}$ et al. (2014a) and Liet al. (2014) was adopted. It is targeted to capture $85 \%$ of the $\mathrm{CO} 2$ with a purity requirement of $98 \mathrm{~mol} \%$ for a comparison with standalone membrane processes. The case study includes simulating the amine process for two solvents, i.e., monoethanolamine (MEA) and diethanolamine (DEA) foracid gas removal from flue gas. A comparison of popular solvents in chemical solvent based separations and strategies to reduce thermal energy consumption through engineered and formulated solvents could be found elsewhere (Chakma, 1997, 1999; Mofarahiet al., 2008). The Pitzer model embedded in ChemCAD was used to calculate the activity coefficients, enthalpies, and Gibbs energies of liquid phase. The fugacity coefficients of the vapor phase were calculated with Redlich-Kwong-Soave equation of state. Rate-based calculation was adopted to get more accurate simulation results as suggested (Zhang et al., 2009). The model is proven to be able to simulate the aqueous absorbent/solvent based $\mathrm{CO}_{2}$ capture process satisfactorily. $\mathrm{CO} 2, \mathrm{~N}_{2}$ and $\mathrm{O}_{2}$ were defined in the system to obey Henry's law.

Inside the stripper, there were two design specifications. The first one was to achieve a desired mass flow of $\mathrm{CO} 2$ in the distillate (commonly $85 \%$ of the $\mathrm{CO} 2$ in the flue gas, calculated from the absorber design specification) by varying the bottom to feed ratio at the bottom of the stripper. The other specification was to achieve a carbon dioxide purity (typically $98 \mathrm{~mol} \% \mathrm{CO} 2$ ) in the product stream by varying the molar reflux ratio at the top of the stripper.

The absorber and stripper models are sensitive to changes in their respective input streams. Moreover, because of the recycle structure of the flowsheet, it is extremely difficult to converge the MEA flowsheet with a closed recycle stream. Since most of the MEA solution entering the stripper is being recycled, a large number of iterations is necessary to converge the large tear streams. A very good initial estimate of the lean MEA flow and composition is desired since an excess of solvent in the absorber can cause divergence. It is difficult to obtain an initial estimate to initialize the stripper, and reasonable ranges for the design specifications in the stripper are also required for ease of convergence.

TABLE I

COLOUMN SEPARATION DATA, ChEMCAD 6.3.1

\begin{tabular}{|l|l|}
\hline Parameters & Coloumn Based Separation Process \\
\hline Flue gas Flow rate & $20,95 \mathrm{kmol} / \mathrm{h}$ \\
\hline Flue gas Temperature & $313 \mathrm{~K}$ \\
\hline Flue gas Pressure & $1 \mathrm{bar}$ \\
\hline Flue gas Concentration & $13 \% \mathrm{vol}$. \\
\hline Lean Solution Flow rate & $80 \mathrm{~L} / \mathrm{min}$ \\
\hline Lean Solution Temperature & $293 \mathrm{~K}$ \\
\hline Lean Solution Pressure & $1 \mathrm{bar}$ \\
\hline Washing Liquid Flow rate & $7.75 \mathrm{~L} / \mathrm{min}$ \\
\hline Washing Liquid Temperature & $288 \mathrm{~K}$ \\
\hline Washing Liquid Pressure & $1 \mathrm{bar}$ \\
\hline CO2 Absorber Diameter & $7.8 \mathrm{~m}$ \\
\hline CO2 Absorber Height & $0.6 \mathrm{~m}$ \\
\hline Stripper Diameter & $1 \mathrm{~m}$ \\
\hline Stripper Height & $0.3 \mathrm{~m}$ \\
\hline Stripper Pressure & $1 \mathrm{bar}$ \\
\hline
\end{tabular}

For the amine absorption process, the number of stages in the absorber and the stripper were arbitrarily chosen to be 10 and 14 ,respectively. Simulations were conducted to optimize the number of stages required for both the absorber and the stripper columns to minimize the reboiler heat duty. The reduction in reboiler heat duty is due to the fact that a greater number of stages in the absorber allows a lower solvent circulation rate in the absorber, and thus reduces th eheat required by the reboiler to regenerate the solvent. It was also observed that the required lean solvent flow rate decreases as the number of stages in the absorber increases. Moreover, as the lean solvent flow rate increases, the diameter of the column increases subsequently, thereby increasing the capital cost of the capture process (Hassan et al., 2007). The number of stages in the absorber and the stripper was finally chosen to be 7 and 10 , respectively.

\section{b. Membrane Proceess Description:}

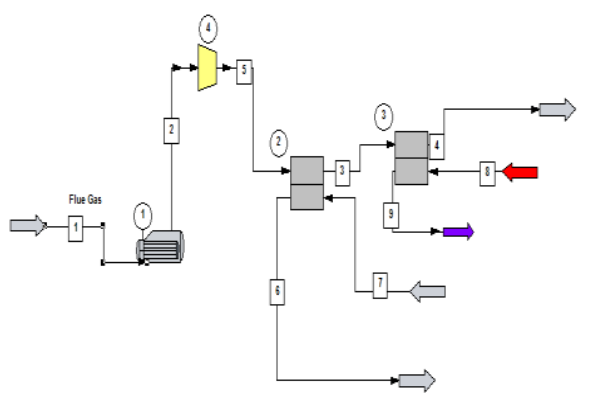

Fig 4. Process Flow Diagram for Membrane Processes

Flue gas which is an outlet stream from a gas turbine in post combustion of landfill gas enters in a boliler in which the $747 \mathrm{~K}$ of temperature is reduced to $313 \mathrm{~K}$. Furtherl, in a compressor it compresses to aproximately $50 \%$ of its own pressure. The outlet stream of the compressor then is being fed to a two stage membrane unit, of which the process parameters will be explained in model description of the process.

\section{Model Description}

The model is implemented in ChemCAD 6.3.1 user added membrane unit (custom unit operation model for hollow fiber membrane module, which is only available in the new versions of ChemCAD 6.)The procedures and modifications required are reported by Chowdhury (2012).It is generally agreed that the membrane area and power consumption for compression and/or vacuum are the key factors determining the cost of membrane processes. Flue gas from power natural gas using landfill power plants were taken as the basis to investigate effectiveness of membrane processes. As membrane replacement is a critical operating cost, pre-treatment of feed stream is neces-sary to extend the membrane life. The feed stream was assumed to have been pretreated before entering the membrane unit and free of minor components such as $\mathrm{SO}_{x}, \mathrm{NO}, \mathrm{CO}, \mathrm{Ar}, \mathrm{H}_{2} \mathrm{O}$ and ash.Certain gas separation membranes cannot handle a high moisture content, and assumed that pre-treatment of the feed gas for water removal is not needed. In the calculation, the gas was assumed to be free of water, and the gas composition was on a dry basis. The gas pre-treatment for water removal will require additional energy which adds to the efficiency penalty of the capture process. The flue gas flow rate, composition, temperature and pressure after the pre-treatment are presented in Table 1. A CO2 capture requirement to recovery of $85 \%$ is somewhat arbitrarily chosen, however, this reflects how aggressively we want to reduce the $\mathrm{CO} 2$ emissions.

The design of membrane gas separation processes involves the determination of appropriate permeator arrange-ments/configurations as well as specification of process unit (i.e.,module) sizes and operating conditions. A single stage arrangement with feed compression and/or permeate vacuum or both(without any recycle stream) is the most common and simplest design consideration. However, a high purity and recovery of the desired product sometimes may require the use of stream recycle and multi-stage 
configurations (Koros and Chern, 1987).The modeling and simulation strategy described as in Chowdhury(2012), Chowdhury et al. (2005), and Kundu et al. (2012) were used to simulate single stage and multi-stage configurations. The membranes were assumed to have an asymmetric structure with an outer dense skin layer supported on a porous substrate. The model took into account of "cross flow" of local permeate with respect to the membrane skin. It was assumed that the porous substrate has negligible resistance to gas flow, and the permeate flow is governed by the Hagen-Poiseuille equation. The permeance of each gas species was considered independent of gas pressure and concentration. The permeator model was based on mass balance over a differential element of the hollow fiber module.

The permeances of membranes are 1000, 50 and20 GPU (Gas Permeation Unit, where $1 \mathrm{GPU}$ is defined as $10-6 \mathrm{~cm} 3(\mathrm{STP}) / \mathrm{cm} 2 \mathrm{~s}$ $\mathrm{cmHg}$, or $3.35 \times 10-10 \mathrm{~mol} / \mathrm{m} 2 \mathrm{~s} \quad \mathrm{~Pa})$ for $\mathrm{CO} 2$, O2and N2,respectively, with CO2/N2selectivity of 50 (Lin et al., 2007). These values will be used throughout the study unless stated otherwise. The compressors were assumed to be polytropic with inter-stage cooling. Polytropic efficiency of compressor is assumed to be of $80 \%$. The power use in compressor is considered as the primary energy required in the membrane process. . The required membrane area increases as more share of the $\mathrm{CO} 2$ is removed with membranes as observed during the process simulation.

TABLE II

Membrane Process Data, Chemcad 6.3.1

\begin{tabular}{|l|l|}
\hline Process variables & Process in Fig.4 \\
\hline Feed CO2, Mole Fraction & 0.241 \\
\hline Total Feed Flow, kmol/s & 2.1042 \\
\hline Temperature, K & 313 \\
\hline Feed Compressor Pressure, $\mathrm{kPa}$ & 2000 \\
\hline $\begin{array}{l}\mathrm{CO} 2 \text { in CO2 -Rich stream, } \\
\text { Mole Fraction }\end{array}$ & 0,98 \\
\hline CO2 Capture Rate & $\% 85$ \\
\hline Membrane Area, $\mathrm{m}^{2}$ & 221 \\
\hline Net Power Consumption, MW & 32.4 \\
\hline $\begin{array}{l}\text { Net Energy Required, GJ/ton } \\
\mathrm{CO} 2 \text { recovered }\end{array}$ & 1.71 \\
\hline
\end{tabular}

\section{CONCLUSION}

To mitigate the greenhouse effect on climate change, carbon capture and storage (CCS) technology is proposed as an effective and attractive pathway for restraining anthropogenic $\mathrm{CO}_{2}$ emissions from coal-fired power plants. Generally, it can be divided into three main categories: post-combustion, pre-combustion, and oxy combustion. A consensus has arisen from the formidable debate on climate change: greenhouse gases such as carbon dioxide do indeed have a significant effect on the global climate. The desire to protect our climate has consequently motivated recent efforts to decrease energy consumption in industrial countries, improve energy efficiency, introduce renewable energy sources and capture and store $\mathrm{CO}_{2}$ from the flue gas of power plants and natural gas streams. Here we address the latter method of $\mathrm{CO}_{2}$ reduction, namely $\mathrm{CO}_{2}$ recovery from flue gas.

The problem, which we will discuss here, is typically referred to as post-combustion capture, and differs significantly from so-called precombustion capture.

Post-combustion capture must treat low-pressure streams with a low concentration of $\mathrm{CO}_{2}$, pre-combustion capture feed streams are typically under high pressure and high $\mathrm{CO}_{2}$ concentration (typically a $30 / 70 \mathrm{CO}_{2} / \mathrm{H}_{2}$ mixture at 20-50 Bar)[29]. However, pre-combustion capture is only an option for fossil-fuel power plants; for other industrial plants $\mathrm{CO}_{2}$ must be captured post-combustion. Several research programs have systematically evaluated these and several other processes for post-combustion capture. Absorption is also the clear favourite industrially: the large majority of commercial $\mathrm{CO}_{2}$ capture plants useamine absorption [2].Unfortunately, liquid amine absorption retains several drawbacks, the most significant being the need for solvent regeneration. When the $\mathrm{CO}_{2}$ is removed from the flue gas via capture by absorption in an amine, a second separation process (e.g. stripping) is required to isolate the $\mathrm{CO}_{2}$ and regenerate the solvent. Gas permeation processes possess several advantages:

(i) high separation energy efficiency relative to equilibrium-based processes (when highly selective materials are used) [7,8];

(ii) industrially established processes, including air separation, hydrogen recovery and carbon dioxide removal from biogas [9];

(iii) high packing density, and therefore relatively small installations. Size intensification is particularly important for carbon dioxide capture given the high flow rates involved [10].

Based on the above arguments, gas separation membranes are often cited as viable alternatives in $\mathrm{CO}_{2}$ capture studies and, conversely, $\mathrm{CO}_{2}$ capture is seen as a promising target for the future membrane market[11-14].

TABLE III

ENERGy REQUiRED FOR CAPTURE TECHOLOGIES, CHEMCAD 6.3.1

\begin{tabular}{|l|l|}
\hline CO2 Capture Technology & Energy GJ/ton CO2 \\
\hline Membrane processes & 1.71 \\
\hline MEA scrubbing & 3.5 \\
\hline DEA scrubbing & 3.9 \\
\hline
\end{tabular}

Membrane processes exhibit the lowest energy demand and can save up to $35-55 \%$ energy compared to the standalone MEA capture processes. However, it was not achievable by amine processes even if hindered amines or engineered solvents were used. Membrane processes can offer significant advantages over amine processes by limiting the energy demand.

\section{ACKNOWLEDGMENT}

'The authors would like to thank Orta Doğu Energy Group for the support. They would also like to acknowledge the Office of Research Support and Sponsored Projects of the Yildiz Technical University.

\section{REFERENCES}

[1] Agency for Toxic Substances \& Disease Registry, Landfill Gas Primer "An Overview for Environmental Health Professionals, Chapter 3"

[2] G. Tchobanoglous, H. Theisen, S. Vigil, "Integrated Solid Waste Management: Engineering Principles and Management Issues" McGraw-Hill, 1993

[3] US Environmental Protection Agency, "LFG Energy Project Development Handbook, Chapter 1: Landfill Gas Energy Basics", 2015

[4] US Environmental Protection Agency, "LFG Energy Project Development Handbook, Chapter 2: Landfill Gas Energy", 2015

[5] IEA Bioenergy, "Biogas Upgrading and Utilization, Task 24: Energy from Biological Conversion of Organic Waste" pp 4-18, 2000.

[6] https://hub.globalccsinstitute.com/publications/ccs-roadmap-industryhigh-purity-CO_2-sources-sectoral-assessment-E2\%80\%93-final-draftreport-3]

[7] T. Turna, "Çöplük Gazlarından Elektrik ve Isı Üretiminde Gaz Motoru Teknolojisi", Chamber of Mechanical Engineers, Book of Proceedings, vol 215, pp. 109-114.

[8] http://www.energyjustice.net/map/biomasshighheatoperating, Access Date: 28.02 .2016

[9] W. M. Budzianowski, "A review of potential innovations for production, conditioning and utilization of biogas with multiple-criteria assessment", Renewable And Sustainable Energy Reviews, vol. 54, pp. 1148-1171, Feb. 2016. http://dx.doi.org/10.1016/j.rser.2015.10.054 
[10] S. S. Burt, A. Baxter, C. Bence, C., L. L. Baxter, "Cryogenic CO2 Capture for Improved Efficiency at Reduced Cost", $201010^{\text {th }}$ Annual Meeting of American Institute of Chemical Engineers

[11] E. Chabanon, R. Bounaceur, C. Castel, S. Rode, D. Roizard, E. Favre, "Pushing the limits of intensified $\mathrm{CO} 2$ post-combustion capture by gasliquid absorption through a membrane contactor", Chemical Engineering and Processing: Process Intensification, vol. 91, May 2015, pp 7-22, http://dx.doi.org/10.1016/j.cep.2015.03.002

[12] Chemical Absorption for Biogas Purification, Brazilian Journal of Chemical Engineering Vol.21 No.3 July-September 2004.

[13] M.S. Horikawa, F. Rossi, M.L. Gimenes, C.M.M. Costa M.G.C. da Silva, "Chemical absorption of H2S for biogas purification", Brazilian Journal of Chemical Engineering, vol. 21, Jul 2004. http://dx.doi.org/10.1590/S0104-66322004000300006

[14] N. Akpinar, "Energy Production from Municipal Solid Wastes", MSc Thesis, Istanbul Technical University, Institute of Energy, July 2006.

[15] O. T. Gülzow, "Biyogaz Klavuzu-Üretimden Kullanıma, Yenilebilir Hammaddeler Ihtisas Ajansı(Fachagentur Nachweisende RohstoffeFNR)" ,Türk-Alman Biyogaz Projesi (Türkisch-Deutsches Biogasprojekt), $5^{\text {th }}$ Edition, ,2010

[16] H. Lin, Z. He, Z. Sun, J. Kniep, A. Ng, R. W. Baker, T. C. Merkel, "CO2-selective membranes for hydrogen production and $\mathrm{CO} 2$ capture Part II: Techno-economic analysis", Journal of Membrane Science, vol. 493, Nov 2015, pp. 794-806.

http://dx.doi.org/10.1016/j.memsci.2015.02.042

[17] T. C. Merkel, H. Lin, X. Wei, R. Baker, "Power plant post-combustion carbon dioxide capture: An opportunity for membranes", Journal of Membrane Science, vol. 359, Sep 2010, pp. 126-139.

http://dx.doi.org/10.1016/j.memsci.2009.10.041 